\title{
Investigation of Laboratory-Scale and Pilot-Scale Attached Growth Ammonia Removal Kinetics at Cold Temperature and Low Influent Carbon
}

Robert Delatolla ${ }^{1}$, Nathalie Tufenkji ${ }^{2}$, Yves Comeau ${ }^{3}$, Alain Gadbois ${ }^{4}$, Daniel Lamarre ${ }^{4}$ and Dimitrios Berk ${ }^{2}$

${ }^{1}$ Department of Civil Engineering, University of Ottawa, Ottawa, Ontario K1N 6N5

${ }^{2}$ Department of Chemical Engineering, McGill University, Montreal, Quebec H3A 2B2, Canada

${ }^{3}$ Civil, Geological and Mining Engineering, Ecole Polytechnique, Montreal, Quebec H3T 1J4, Canada

${ }^{4}$ Veolia Water, Montreal, Quebec H4S 2B3, Canada 


\begin{abstract}
A mobile testing center was installed at a lagoon wastewater treatment plant (WWTP) at Terrebonne, Canada to investigate the rate of ammonia removal of attached growth treatment systems at $4^{\circ} \mathrm{C}$ and at low influent carbon concentrations. The testing center housed two laboratory-scale reactors, a pilotscale BioStyr system (Veolia Water) and a pilot-scale moving bed bioreactor (MBBR) system (Veolia Water). Although the rates of laboratory-scale and the pilot-scale systems demonstrated that the exposure time to low temperature has a significant effect on the kinetics of the system, the ammonia removal rates of all the systems were shown to be significant at $4^{\circ} \mathrm{C}$. A strong correlation was demonstrated between the rates of ammonia removal produced by the laboratory-scale reactors, the pilot BioStyr system and pilot MBBR system; thus verifying the scale-up capability of the laboratoryscale reactors and demonstrating that nitrifiers can achieve ammonia removal under cold temperature conditions for elapsed periods of time independent of the reactor design. Finally, the ammonia removal rates of the laboratory-scale systems, the BioStyr pilot system and the MBBR pilot system were all accurately predicted by a recently proposed Theta model.
\end{abstract}

Keywords: BioStyr; moving bed bioreactor; cold temperature; ammonia removal; pilot-scale; wastewater treatment, scale-up. 


\section{Introduction}

The biological process of nitrification is currently the most economical and widely employed means of removing ammonia from wastewater (Metcalf \& Eddy 2003). In Canada, lagoon treatment systems account for approximately $70 \%$ of the wastewater treatment plants (WWTP). Due to regional climates, the temperatures in these treatment plants drop to as low as $4^{\circ} \mathrm{C}$ for extended periods of time during the winter months. To date, research has demonstrated discrepancies in the ability of suspended growth nitrifiers to achieve ammonia removal at low temperatures. While Oleszkiewicz and Berquist (1988) have shown that nitrifiers are capable of significant rates of ammonia removal below $5^{\circ} \mathrm{C}$ for a short period of time, a number of other studies have demonstrated that no nitrifier growth occurs below $4^{\circ} \mathrm{C}$ (Buswell et al. 1954; Painter and Loveless 1983; McCartney and Oleszkiewicz 1990; Dyke et al., 2003).

Notwithstanding the discrepancy in the findings of past studies of suspended growth treatment systems at low temperatures, there is evidence that attached growth ammonia removal processes have the potential to consistently achieve ammonia removal at low temperatures (WEF 1998). In addition, biological aerated filtration (BAF) treatment systems, which are attached growth treatment systems, have shown improved rates and maintenance of ammonia removal over traditional, suspended growth treatment systems (Le Tallec et al. 1997; Payraudeau et al. 2000). This ability of attached growth nitrifiers to maintain ammonia removal throughout winter conditions has identified BAF treatment systems as a potential solution for ammonia removal from Canadian wastewaters all year round. These BAF treatment systems may be incorporated within the current lagoon infrastructure as an upgrade to the current treatment system. 
In addition to nitrifiers being affected by low temperatures, wastewater characteristics such as organic carbon load also impact these organisms. The influent organic carbon loading has shown to strongly influence ammonia removal rates in attached growth treatment systems (Lazarova et al. 1999). Average influent carbon concentrations of municipal wastewaters of approximately $400 \mathrm{mg} / \mathrm{L}$ of COD cause the rapidly growing, heterotrophic bacterial population to dominate the surface of the substratum and in turn impede the rate of ammonia removal; whereas low carbon concentrations of approximately $100 \mathrm{mg} / \mathrm{L}$ of COD or less reduce this smothering effect of the heterotrophic population and thus the activity of the nitrifiers is impeded to a lesser extent (Aravinthan et al. 1998). Hence, the likelihood of removing ammonia from lagoon treatment systems during the winter months is improved if the ammonia removal upgrade system receives wastewaters that already underwent carbon removal treatment. Wastewaters characterized by lower carbon concentrations of approximately 100 $\mathrm{mg} / \mathrm{L}$ are common at the exit of the first pond of a lagoon treatment system. This wastewater, having exited from the first pond of the lagoon treatment system, can be diverted to the ammonia removal treatment system where the ammonia removal process is less likely to be impeded by high carbon concentrations. Hence, the ability of attached growth treatment systems to serve as ammonia removal upgrades to lagoon treatment systems in northern climates is dependent upon the ability of nitrifiers to achieve significant rates of ammonia removal at $4^{\circ} \mathrm{C}$ and under low carbon load conditions.

The objective of this study is to investigate ammonia removal of attached growth treatment systems at $4^{\circ} \mathrm{C}$ and at low influent carbon concentrations that is representative of inlet conditions to lagoon upgrade treatment systems. Specifically, this study examines the performance of a mobile 
testing center at a lagoon WWTP at Terrebonne, Canada during the winter months. The testing center housed two BAF, laboratory-scale reactors that are designed to replicate the BioStyr treatment system (Veolia Water), a pilot-scale BioStyr system and a pilot-scale moving bed bioreactor (MBBR) (Veolia Water). Measurements of ammonia removal rates in the laboratory-scale reactors and the BioStyr pilot facility serve to verify the scale-up potential of the laboratory-scale reactors, while a comparison between the kinetics of the BioStyr pilot and the MBBR pilot provide an evaluation of the attached growth nitrifiers in different treatment systems.

\section{Material and Methods}

\section{Study Site}

This study was conducted at the Terrebonne WWTP in Quebec, Canada. A mobile testing center was installed at the Terrebonne treatment plant between October 2007 and April 2008. This testing center housed two laboratory-sized reactors, a pilot BioStyr system and a pilot MBBR system. The laboratory-sized reactors and pilot plants were fed from wastewater drawn from the exit of the first lagoon of the Terrebonne treatment plant. This effluent stream was selected because it has been proposed that upgrades to current lagoon treatment systems in Canada may be best implemented as a treatment system in series with current ponds of the lagoon treatment plant. Specifically, the added treatment system should receive treated water from the first pond and subsequently release its effluent into the subsequent ponds of the treatment train. Although the temperature of the wastewater is lower at the exit of the first pond as compared to the inlet source of the lagoon, the lower carbon concentrations exiting the first pond should enable higher rates of ammonia removal within the 
additional treatment reactor. Thus, wastewater exiting from the first lagoon was collected in the mobile testing center and fed to the laboratory-scale reactors and the pilot systems. Due to large fluctuations in the wastewater conditions, the collected water was dosed with ammonia, phosphorous and alkalinity prior to entering the laboratory-sized reactors and the pilot scale treatment systems. Dosing of the collected wastewater was performed to eliminate the effects of low phosphorous concentrations or low $\mathrm{pH}$ values on the rate of ammonia removal, thus isolating the effects of temperature on ammonia removal rate. Ammonia levels were also dosed to minimize diurnal fluctuations of influent ammonia concentrations and thus promote steady state conditions that subsequently facilitated the calculation of ammonia removal rates. The wastewater entering the laboratory-sized and pilot scale systems was characterized by a $\mathrm{pH}$ ranging between 7.0 to 7.5 ; COD ranging between 45 and $155 \mathrm{mg} / \mathrm{L}$; and $\mathrm{NH}_{4}^{+}$concentrations varying between 10 and $20 \mathrm{mg}-\mathrm{N} / \mathrm{L}$. Independent cooling systems were connected to the laboratory reactors and the pilot plants in order to maintain the temperature within the treatment systems between 3 and $4^{\circ} \mathrm{C}$.

\section{Laboratory-Scale Reactors}

Two identical laboratory-scale reactors denoted as R1 and R2 were designed to simulate the BAF, BioStyr treatment system. These reactors are identical to the two laboratory reactors used in Delatolla et al. (2009) and are a scale-down version of the BioStyr pilot system operated in this study. The reactors consist of two components, the main reactor and an aeration basin, between which the fluid is recirculated via a recirculation pump. The packed bed within the main reactor contains polystyrene, $3.8 \pm 1.2 \mathrm{~mm}$ diameter bead substrata. The packed bed volume of both reactors was $90 \mathrm{~mL}$. The 
reactor design incorporates a recirculation system in order to ensure a constant fluid rise rate within the reactors. The addition of the recirculation pump ensures a constant superficial velocity within the packed bed and it enables the reactors to approach completely mixed flow conditions.

Data were collected from the two laboratory-sized reactors, which were run in parallel from January to April 2008. Both reactors were inoculated with the beads from the pilot-scale system prior to the beginning of the experimental phase and fed from the same wastewater source, aerated with identical aeration pumps at the same aeration rate, and cooled with the same chiller system to maintain the temperature at $4^{\circ} \mathrm{C}$. The temperatures within the reactors were maintained at approximately $14^{\circ} \mathrm{C}$ for a period of one month prior to the installation of the chillers. Following the 30 days at $14^{\circ} \mathrm{C}$, the chiller systems were initiated and used to maintain the temperature within the reactors at $4^{\circ} \mathrm{C}$. The hydraulic retention time (HRT) was $7 \frac{1}{2} \mathrm{~h}$, the superficial velocity was maintained at $1.3 \mathrm{~m} / \mathrm{h}$ with the recirculation pumps, and the dissolved oxygen (DO) was maintained above $5 \mathrm{mg} / \mathrm{L}$ for the entire experimental phase. The DO values were therefore never limiting within the reactors (Knowles et al. 1965).

\section{BioStyr Pilot System}

Data were collected from the pilot-scale BioStyr treatment system between January and April 2008. The BioStyr pilot, shown in Fig. 1, was designed to simulate a full scale BAF, BioStyr WWTP. The packed bed within this pilot system also contained polystyrene, $3.8 \pm 1.2 \mathrm{~mm}$ diameter bead substrata. The packed bed volume was $300 \mathrm{~L}$. The packed bed of the pilot plant was inoculated using sludge from the Terrebonne lagoon treatment system. Once the system was inoculated, the BioStyr pilot system was operated at a temperature that varied between $8^{\circ} \mathrm{C}$ and $6^{\circ} \mathrm{C}$ for approximately $3 \frac{1 / 2}{2}$ months 
prior to the installation of the chiller system. The chiller system was used to reduce the temperature to an average value below $4^{\circ} \mathrm{C}$ for a period of one week. The HRT was between 1.0 to $1.2 \mathrm{~h}$, the superficial velocity was between 2.5 and $3.0 \mathrm{~m} / \mathrm{h}$, and the DO was maintained above $5 \mathrm{mg} / \mathrm{L}$ for the entire experimental phase.

\section{MBBR Pilot System}

Data were collected from the pilot-scale MBBR treatment system over the same timeframe as the laboratory-sized reactors and the BioStyr pilot system. The MBBR pilot system, shown in Fig. 2, consists of two aerated basins in series. Each basin volume is 60\% filled with Kaldnes, polyethylene, cylindrical-shaped substrata. The Kaldnes substrata measure $10 \mathrm{~mm}$ in diameter and $7 \mathrm{~mm}$ in height with a cross inside the cylinder and longitudinal fins along the exterior of the cylinders. These substrata are continually suspended, and circulated within the basins by mechanical aeration. The first basin contains $120 \mathrm{~L}$ of substrata and the second basin contains $143 \mathrm{~L}$ of substrata. This pilot plant was also inoculated using sludge from the Terrebonne lagoon treatment system and the temperature within the MBBR pilot system also varied between $8^{\circ} \mathrm{C}$ and $6^{\circ} \mathrm{C}$ for approximately $3^{1 / 2}$ months prior to the installation of the chiller system to reduce the temperature to an average value below $4^{\circ} \mathrm{C}$ for a period of one week. The HRT was between 1.8 to $2.0 \mathrm{~h}$ and the DO was maintained above $5 \mathrm{mg} / \mathrm{L}$ during the entire experimental phase.

The BioStyr and MBBR pilot systems were both operated at an average value below $4^{\circ} \mathrm{C}$ for a period of one week, as compared to approximately 6 weeks for the laboratory-scale reactors, due to difficulties encountered in the field in cooling the inlet wastewater to these high-flow, field-scale pilot 
systems. Thus, the one week period that the pilot systems remained at an average value below $4^{\circ} \mathrm{C}$ will be compared in this study to the laboratory-scale reactors.

\section{Analysis}

Grab samples of $\mathrm{NH}_{4}{ }^{+}-\mathrm{N}$ were measured by Standard Method $4500-\mathrm{NH}_{3}$ B \& C (APHA, 1995) with $\mathrm{HACH}$ spectrophotometry at $425 \mathrm{~nm},(8038 \mathrm{HACH}, \mathrm{CO}$, USA). Grab samples were acquired approximately every second day in the laboratory-scale reactors for the first two weeks of the experimental phase; grab samples were taken intermittently in the laboratory reactors in the middle of the experimental phase; and grad samples were taken every second day at the end of the experimental phase. Grab samples were acquired every second day in the pilot-scale systems throughout the experimental phase. Autosampler $\mathrm{NH}_{4}{ }^{+}-\mathrm{N}$ measurements were performed using an autosampler, ammonia analyzer (F070905 Tethys Instruments, NY, USA), according to quantitative microdetermination of gaseous ammonia by absorption (Gunther et al., 1956). Samples were analyzed by the autosampler analyzer every hour in the laboratory-scale reactors and the pilot systems. Due to limited autosampler ports the two laboratory-scale reactors shared one common port. Thus each laboratory-scale reactor was connected to the autosampler for a period of 3 to 6 days and then taken off-line while the other reactor was connected to the autosampler. COD was measured using digestion and spectrophotometry (8000, HACH, CO, USA) according to Standard Method 5200 D (APHA, 1995). 


\section{Results and Discussion}

\section{Laboratory-Scale Reactors}

The laboratory-scale reactors remained between 3 and $4^{\circ} \mathrm{C}$ for a period of 40 days. The influent COD that entered the laboratory-scale reactors, along with the temperature, the $\mathrm{pH}$ and $\mathrm{DO}$ values measured are shown in Fig. 3. The temperature, $\mathrm{pH}$ and $\mathrm{DO}$ were steady within both reactors; however, the influent COD dropped at the end of March. The COD entering the reactors at the end of March decreased due to warmer conditions and a corresponding increase in the heterotrophic activity in the first lagoon of the Terrebonne treatment plant that served as the source of municipal wastewater.

Figures $4 \mathrm{a}$ and $4 \mathrm{~b}$ demonstrate the rate of ammonia removal within reactors $\mathrm{R} 1$ and $\mathrm{R} 2 \mathrm{during}$ the $4^{\circ} \mathrm{C}$ period. The rates were calculated at steady state conditions by:

$$
R_{\mathrm{A}}=\left(C_{\mathrm{Af}}-C_{\mathrm{A}}\right) \times Q / V_{\mathrm{b}}
$$

where $R_{\mathrm{A}}$ is the rate of ammonia removal, $C_{\mathrm{Af}}$ and $C_{\mathrm{A}}$ are the inlet and outlet concentrations of ammonia, respectively, $Q$ is the flow rate in and out of the reactors and $V_{\mathrm{b}}$ is the bed volume of beads within the reactors.

It should be noted that hourly and daily fluctuations of the influent ammonia concentration caused hourly and daily fluctuations in the rate of ammonia removal within both reactors. Thus, autosampler and grab sample rates were dependent upon the time of day that the sampling was performed. For the sake of clarity, Fig. 4 displays the average and standard deviation of the ammonia rates recorded by the autosampler for each 24 hour sampling period. Measurements conducted on grab samples and the results from the autosampler compared well for reactor R1, whereas R2 
demonstrated autosampler rates of ammonia removal that were generally elevated when compared to the grab sample data. The autosampler results of R2 are believed to be erroneously high due to the autosampler's sampling tube position within reactor R2, which caused air bubbles to be pumped into the autosampler with the sample.

The results presented in Fig. 4 demonstrate that a significant removal rate is observed within reactors $\mathrm{R} 1$ and $\mathrm{R} 2$ even after 40 days between 3 and $4^{\circ} \mathrm{C}$. The rate dropped in $\mathrm{R} 1$ from approximately $0.60 \mathrm{~kg}-\mathrm{N} / \mathrm{m}^{3} / \mathrm{d}$ at $14^{\circ} \mathrm{C}$ to approximately $0.16 \mathrm{~kg}-\mathrm{N} / \mathrm{m}^{3} / \mathrm{d}$ after 40 days between 3 and $4^{\circ} \mathrm{C}$. Reactor R2 also showed a drop in the rate of ammonia removal during the cold period; the rate decreased from approximately $0.80 \mathrm{~kg}-\mathrm{N} / \mathrm{m}^{3} / \mathrm{d}$ at $14^{\circ} \mathrm{C}$ to approximately $0.22 \mathrm{~kg}-\mathrm{N} / \mathrm{m}^{3} / \mathrm{d}$ after 40 days at $4^{\circ} \mathrm{C}$.

The change in temperature from $14^{\circ} \mathrm{C}$ to $4^{\circ} \mathrm{C}$ was very abrupt within these experiments and occurred within 24 hours, as shown by the temperature profiles in Fig. $4 \mathrm{a}$ and $4 \mathrm{~b}$. Thus, the reactors experienced a temperature shock from $14^{\circ} \mathrm{C}$ down to $4^{\circ} \mathrm{C}$. The effect of this temperature shock is observed in both reactors where the rate of ammonia removal dropped significantly the first day at $4^{\circ} \mathrm{C}$ and started to slowly increase during the second and third days at $4^{\circ} \mathrm{C}$. This immediate adverse impact on the nitrifiers due to abrupt temperature changes was also shown by Andersson et al. (2001) as well as Hwang and Oleszkiewicz (2007).

Following the first three days at $4^{\circ} \mathrm{C}$, the rates of ammonia removal continually decreased while both reactors remained just below $4^{\circ} \mathrm{C}$. This decrease in ammonia removal with exposure time to $4^{\circ} \mathrm{C}$, as shown in Fig. 4a and 4b, demonstrates that the exposure time at cold temperature is an important factor that affects the rate of removal. During the last two weeks at $4^{\circ} \mathrm{C}$, however, the change in the rates became smaller, showing a tendency for the rates of ammonia removal to stabilize. This decrease 
in the rates of ammonia removal as a function of exposure time to $4^{\circ} \mathrm{C}$ is consistent with the findings of Delatolla et al. (2009) which demonstrate a significant decrease in the rates of ammonia removal during a six week period at $4^{\circ} \mathrm{C}$ followed by a gradual decrease in the kinetics for the following two and a half months.

An Arrhenius-type, temperature dependent equation used to model the rate of ammonia removal as a function of elapsed time was previously proposed by Delatolla et al. (2009):

$$
\theta=3.81 \times 10^{-2} \cdot \ln (t)+9.83 \times 10^{-1}
$$

where $\theta$ is the temperature correction coefficient and $t$ is the elapsed time at $4^{\circ} \mathrm{C}$. Equation 2 was developed by Delatolla et al. (2009) based on laboratory experiments, where the temperature, $\mathrm{pH}$ and loading rates were controlled and steady throughout the experiments. Calculations based on equation 2 are plotted in Fig. 4a and $4 \mathrm{~b}$ as a solid line. Equation 3 shown below is used to calculate the rate of ammonia removal that corresponds to the $\theta$-value calculated in equation 2 .

$$
K_{2}=K_{1} \cdot \boldsymbol{\theta}^{(T 2-T I)}
$$

In equation 3, $K_{1}$ and $K_{2}\left(\mathrm{~kg}-\mathrm{N} / \mathrm{m}^{3} / \mathrm{d}\right)$ are the ammonia removal rates at temperatures $T 1$ and T2 $\left({ }^{\circ} \mathrm{C}\right)$, respectively. Since both laboratory-scale reactors were maintained at an average temperature of $14^{\circ} \mathrm{C}$ for a month prior to reducing the temperature to $4^{\circ} \mathrm{C}$, steady kinetics rates of ammonia removal were well established at $14^{\circ} \mathrm{C}$. Thus, in the calculations presented in Fig. $4 \mathrm{a}$ and $4 \mathrm{~b}, T 1$ was set to $14^{\circ} \mathrm{C}$ and $K_{l}$ was set to the average rate of ammonia removal at $14^{\circ} \mathrm{C}$ in reactors $\mathrm{R} 1$ and $\mathrm{R} 2$, respectively. This calculation assumes that ammonia removal is zero order above ammonia concentrations of $5 \mathrm{mg}-\mathrm{N} / \mathrm{L}$ (USEPA 1993); in fact, the ammonia concentration never dropped below $5 \mathrm{mg}-\mathrm{N} / \mathrm{L}$ in this study. 
A strong correlation exists between the Delatolla et al. (2009) Theta model and the rates of ammonia removal shown in reactors $\mathrm{R} 1$ and $\mathrm{R} 2$ of this study. The coefficient of determination $\left(R^{2}\right)$ for a regression analysis between the Theta model and the $\mathrm{R} 1$ data is 0.89 , while the $R^{2}$ value for a comparison between the Theta model and the $\mathrm{R} 2$ data is 0.80 . Therefore, the Theta model provides a good estimate of the rate of removal for both reactors. Fig. 4a shows that the Theta model predictions lie between the grab sample results and the autosampler results of reactor R1 throughout the entire experimental phase. While the measured rate of ammonia removal after 40 days at $4^{\circ} \mathrm{C}$ was $0.16 \mathrm{~kg}$ $\mathrm{N} / \mathrm{m}^{3} / \mathrm{d}$, the Theta model predicts a rate of $0.19 \mathrm{~kg}-\mathrm{N} / \mathrm{m}^{3} / \mathrm{d}$. The grab sample and autosampler results of reactor R2 (Fig. 4b), however, exhibit more fluctuations in the rates of removal. The Theta model proposed by Delatolla et al. (2009) again predicts values between the grab samples and the autosampler results. The rate of ammonia removal for reactor $\mathrm{R} 2$ after 40 days at $4^{\circ} \mathrm{C}$ was $0.22 \mathrm{~kg}-\mathrm{N} / \mathrm{m}^{3} / \mathrm{d}$ and the Theta model predicts a rate of $0.25 \mathrm{~kg}-\mathrm{N} / \mathrm{m}^{3} / \mathrm{d}$.

It should be noted that the same reactor design as Delatolla et al. (2009) was used in this study. However, the current study was conducted in the field and thus used municipal wastewater as reactor feed material. Also, carbon was present within the feed of this study as opposed to Delatolla et al. (2009) who used a synthetic wastewater devoid of carbon. A comparison between the results of this study and the results of Delatolla et al. (2009) demonstrate that the ammonia removal kinetics of the reactors at cold temperatures and low carbon loadings observed in this study display a similar trend to the results of Delatolla et al. (2009); where the removal rate of both R1 and R2 stabilized after 6 weeks at temperatures of approximately $4^{\circ} \mathrm{C}$ in both studies. These experiments also demonstrate that the attached growth reactors used in this research are capable of removing ammonia from municipal 
wastewater at a temperature of approximately $4^{\circ} \mathrm{C}$ for a period of 6 consecutive weeks in the presence of low carbon concentrations. The similar trends between the ammonia removal rates observed in this study and those found by Delatolla et al. (2009) demonstrate that influent COD concentrations lower than $100 \mathrm{mg} / \mathrm{L}$ do not influence the rate of ammonia removal of attached growth treatment systems. This observation is confirmed by the strong correlation of the Theta model developed by Delatolla et al. (2009) and the laboratory-scale reactor results of this study. Thus, it can be concluded that low COD concentrations of $100 \mathrm{mg} / \mathrm{L}$ restrain the heterotrophic growth in the reactors and subsequently prevent these organisms from smothering the nitrifying bacterial community.

\section{Pilot systems}

The BioStyr and MBBR pilot systems remained at approximately $4^{\circ} \mathrm{C}$ for a period of 7 days. The influent COD that entered the BioStyr and MBBR pilot reactors, along with the temperature, the $\mathrm{pH}$ and $\mathrm{DO}$ values are shown in Fig. 5. The COD, temperature, $\mathrm{pH}$ and $\mathrm{DO}$ were steady within both pilot systems during the entire experimental phase at $4^{\circ} \mathrm{C}$. The temperature, $\mathrm{pH}$ and $\mathrm{DO}$ were also comparable to the laboratory-scale reactors during this period. The influent COD, however, was significantly lower within the pilot systems than the laboratory-scale reactors. These lower influent $\mathrm{COD}$ concentrations were due to the fact that the pilot systems were lowered to $4^{\circ} \mathrm{C}$ at the beginning of April when the COD was decreasing in the Terrebonne treatment plant as a result of warmer conditions and increased heterotrophic activity.

Figures $6 \mathrm{a}$ and $6 \mathrm{~b}$ demonstrate the rate of ammonia removal within the BioStyr and MBBR pilot systems, respectively, during the $4^{\circ} \mathrm{C}$ experimental phase. These data demonstrate that a 
significant rate of ammonia removal occurs within both pilot systems after 7 days at approximately $4^{\circ} \mathrm{C}$ and $3 \frac{1 / 2}{2}$ months between $8^{\circ} \mathrm{C}$ and $6^{\circ} \mathrm{C}$. The removal rate within the BioStyr pilot system dropped from approximately $0.26 \mathrm{~kg}-\mathrm{N} / \mathrm{m}^{3} / \mathrm{d}$ at $8^{\circ} \mathrm{C}$ to approximately $0.18 \mathrm{~kg}-\mathrm{N} / \mathrm{m}^{3} / \mathrm{d}$ after 7 days at $4^{\circ} \mathrm{C}$. The MBBR pilot-scale reactor also showed a drop in the rate of ammonia removal. The rate decreased from approximately $0.21 \mathrm{~kg}-\mathrm{N} / \mathrm{m}^{3} / \mathrm{d}$ at $8^{\circ} \mathrm{C}$ to approximately $0.14 \mathrm{~kg}-\mathrm{N} / \mathrm{m}^{3} / \mathrm{d}$ after 7 days at $4^{\circ} \mathrm{C}$.

As noted above, the autosampler and grab sample rates were dependent upon the time of day that the sampling was performed. The autosampler and grab sample results compared well for both pilot systems throughout the week that the systems were maintained at $4^{\circ} \mathrm{C}$. However, the recorded autosampler rates for both pilot systems showed significant variances during periods of temperature fluctuations. Nonetheless, the overall trend of the rates of ammonia removal shows a continual decrease during the 7 day period at $4^{\circ} \mathrm{C}$. This decrease in ammonia removal rates with exposure time to $4^{\circ} \mathrm{C}$ (Fig. 6) is consistent with the laboratory-scale reactor results (Fig. 4) and the results previously presented by Delatolla et al. (2009). Thus, at the pilot scale, the exposure time to cold temperature is also an important factor affecting the rate of removal.

Figure 6 shows that the proposed Theta model also provides a good estimate of the rate of removal for both pilot systems throughout the experimental phase at $4^{\circ} \mathrm{C}$ by predicting the decrease in kinetics with increased exposure to $4^{\circ} \mathrm{C}$. Since both pilot systems were operated at a temperature between 6 and $8^{\circ} \mathrm{C}$ for $3 \frac{1}{2}$ months prior to reducing the temperature to $4^{\circ} \mathrm{C}$, the average temperatures and the steady kinetics of ammonia removal in this period of operation were used to set $T 1$ and $K_{1}$ in equation 3. The $R^{2}$ value determined from a regression analysis between the Theta model and the BioStyr data is 0.83. The average rate of ammonia removal for the BioStyr pilot after 7 days at $4^{\circ} \mathrm{C}$ 
and the predicted rate of removal by the Theta model were both approximately $0.18 \mathrm{~kg}-\mathrm{N} / \mathrm{m}^{3} / \mathrm{d}$. The $R^{2}$ value calculated from a regression analysis between the Theta model and the MBBR data is 0.84 . The average rate of ammonia removal for the MBBR pilot after 7 days at $4^{\circ} \mathrm{C}$ and the predicted rate of removal by the Theta model were both approximately $0.14 \mathrm{~kg}-\mathrm{N} / \mathrm{m}^{3} / \mathrm{d}$.

Although a similar trend in the kinetics of ammonia removal with exposure time to $4^{\circ} \mathrm{C}$ can be observed between the laboratory-scale reactors and the pilot-scale treatment plants, the different times of exposure to $4^{\circ} \mathrm{C}$ provide difficulties in directly observing similarities or differences between the laboratory reactors and the pilot plants. Nevertheless, the ability of the Theta model to predict the trend of ammonia removal kinetics at the laboratory-scale and at the pilot-scale demonstrates that a strong correlation exists between the kinetics of ammonia removal irrespective of the scale differences. Also, the ability of the Theta model to predict the rates of ammonia removal within both the BioStyr and MBBR pilot systems demonstrates that ammonia removal under cold temperature conditions for extended periods of time may be well characterized in different reactors by a single model.

\section{Conclusion}

This study on rates of attached growth ammonia removal at low temperatures within laboratory-scale and pilot scale wastewater treatment systems under low influent carbon municipal wastewater conditions presents the following conclusions:

- Significant rates of ammonia removal were observed within the two laboratory-scale reactors after 40 days at $4^{\circ} \mathrm{C}$ and within the BioStyr pilot and the MBBR pilot after $31 / 2$ months between $8^{\circ} \mathrm{C}$ and $6^{\circ} \mathrm{C}$ and 7 days at $4^{\circ} \mathrm{C}$. 
- Ammonia removal rates at $4^{\circ} \mathrm{C}$ within the laboratory-scale and pilot-scale systems demonstrated that the exposure time to $4^{\circ} \mathrm{C}$ has a significant effect on the kinetics of the system. The kinetics within the laboratory-scale reactors appears to begin stabilizing after 6 weeks at $4^{\circ} \mathrm{C}$, which is consistent with previous findings (Delatolla et al. 2009).

- The rates of ammonia removal of the laboratory-scale reactors and the pilot BioStyr system showed a significant correlation, thereby verifying the scale-up capability of the laboratory-scale reactors.

- The rates of ammonia removal of the BioStyr pilot system and the MBBR pilot system showed a strong correlation, thus demonstrating that nitrifiers can achieve similar ammonia removal under cold temperature conditions for both reactor systems.

- The ammonia removal rates of the laboratory-scale systems, the BioStyr pilot system and the MBBR pilot system were accurately predicted by the Theta model proposed by Delatolla et al. (2009).

\section{Acknowledgements}

The authors are indebted to Ms. Virginie McMurray-Beaulieu, Ms. Geneviève Leriche and Ms. Edith Laflamme (Veolia Water) for their gracious help with the data analysis, reactor maintenance and data interpretation. The authors graciously thank Ecole Polytechnique of Montreal and Veolia Water for the use of their mobile test center and pilot plants. The authors acknowledge financial support from Veolia Water, NSERC and the Eugenie Ulmer Lamothe (EUL) fund at McGill University. 


\section{References}

Andersson A, Laurent P, Kihn A, Prevost M, Servais, P. 2001. Impact of temperature on nitrification in biological activated carbon (BAC) filters used for drinking water treatment. Water Res. 35:2923-2934.

APHA, AWWA and WEF. 1995. Standard Methods for the Examination of Water and Wastewater. 19 ${ }^{\text {th }}$ edn,

American Public Health Association/American Water Works Association/Water Environment.

Federation Washington DC, USA. Aravinthan V, Takizawa S, Fujita K, Komatsu K. 1998. Factors affecting nitrogen removal from domestic wastewater using immobilized bacteria. Water Sci. Technol. 38:193-202.

Buswell AM, Shiota T, Lawrence N, Meter IV. 1954. Laboratory studies on the kinetics of the growth of Nitrosomonas with relation to the nitrification phase of BOD test. Appl. Microbiol. 2:21-25.

Delatolla R, Tufenkji N, Comeau Y, Gadbois A, Lamarre D, Berk D. 2009. Kinetic analysis of attached growth nitrification in cold climates. Water Sci. Technol. 60(5):

1173-1184.

Dyke SV, Jones S, Ong SK. 2003. Cold weather nitrogen removal deficiencies of aerated lagoons. Envir. Technol. 24:767-777.

Gunther FA, Barkley JH, Kolbezen R, Blinn C, Staggs EA. 1956. Quantitative Microdetermination of Gaseous Ammonia by its Absorption at 204.3 M . Anal. Chem. 28(12):1985-1989.

Hwang JH, Oleszkiewicz JA. 2007. Effect of cold-temperature shock on nitrification. Water Environ. Res. 79: 964-968.

Knowles G, Downing AL, Barret MJ. 1965. Determination of kinetic nitrifying biomass biological filters used in drinking water production. J. Ind. Microbiol. Biotechnol. 38:263- 278.

Lazarova V, Bellahcen D, Manem J, Stahl DA, Rittmann BE. 1999. Influence of operating conditions on population dynamics in nitrifying biofilms. Water Sci. Technol. 39:5-11.

Le Tallec X, Zeghal S, Vidal A, Lesouef A. 1997. Effect of influent quality variability on biofilter operation. Water Sci. Technol. 36:111-117.

McCartney DM, Oleszkiewicz JA. 1990. Carbon and nutrient removal in a sequencing batch reactor at low temperatures. Envir. Technol. 11:99-112.

Metcalf and Eddy. (2003). Wastewater engineering - treatment and reuse, $4^{\text {th }}$ edn, McGraw- Hill, New York, NY.

Oleszkiewicz JA, Berquist SA. 1988. Low temperature nitrogen removal in sequencing $\quad$ batch reactors. Water Res. 22:1163-1171.

Painter HA, Loveless JE. 1983. Effect of temperature and $\mathrm{pH}$ value on the growth-rate constants of nitrifying bacteria in the activated-sludge process. Water Res. 17:237-248.

Payraudeau M, Paffoni C, Gousailles M. 2000. Tertiary nitrification in an up flow biofilter on floating media: influence of temperature and COD load. Water Sci. Technol. 41:21-27. USEPA (US Environmental Protection Agency). 1993. Nitrogen control manual. Washington, D.C.

WEF (Water Environment Federation). 1998. Biological and chemical systems for nutrient removal. Special publication, Alexandria, VG. 
Figures

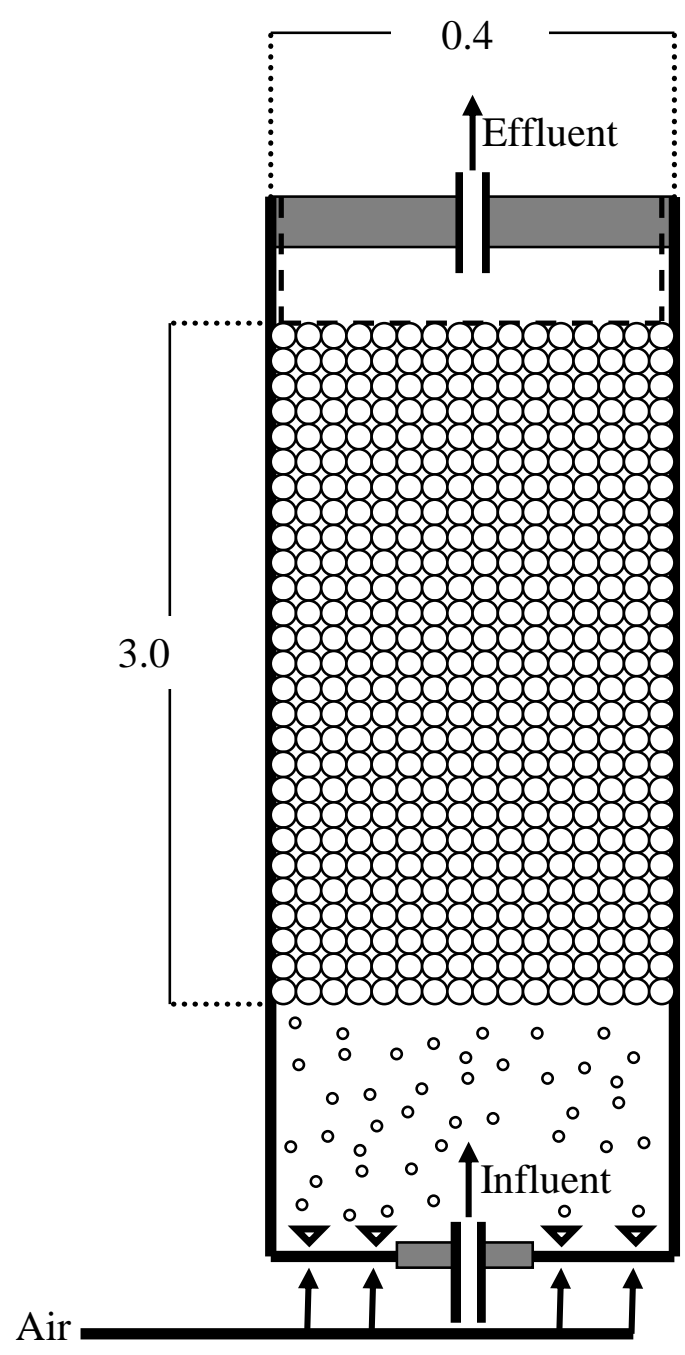

Fig. 1. Schematic of BioStyr pilot system, geometry of system is cylindrical, dimensions are in meters. Packed bed volume is 300L. 


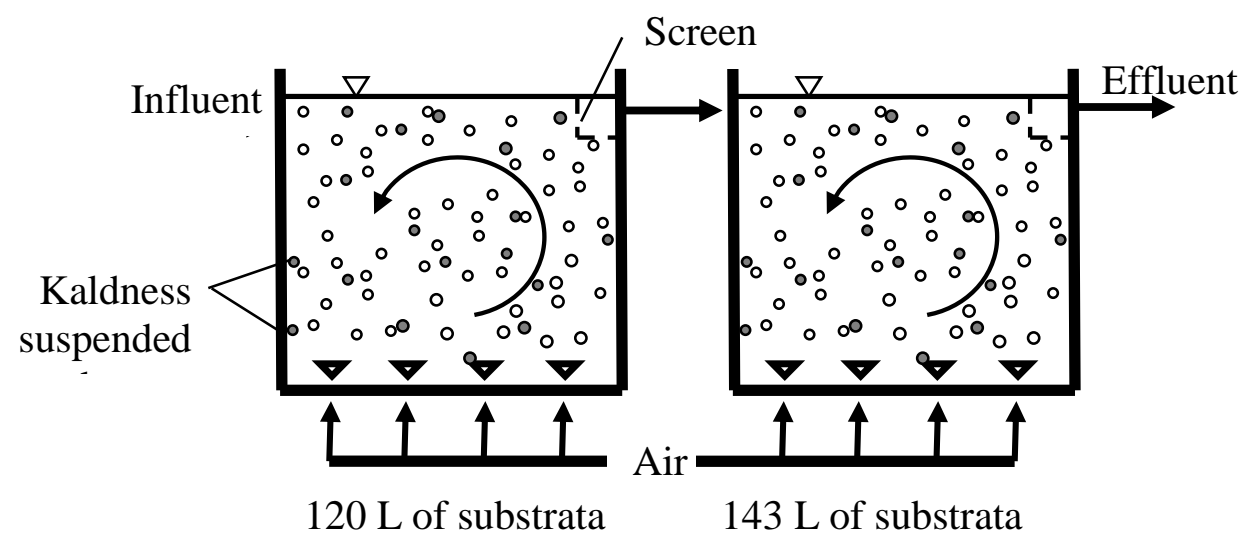

Fig. 2. Schematic of MMBR pilot system, geometry of basins are cylindrical.

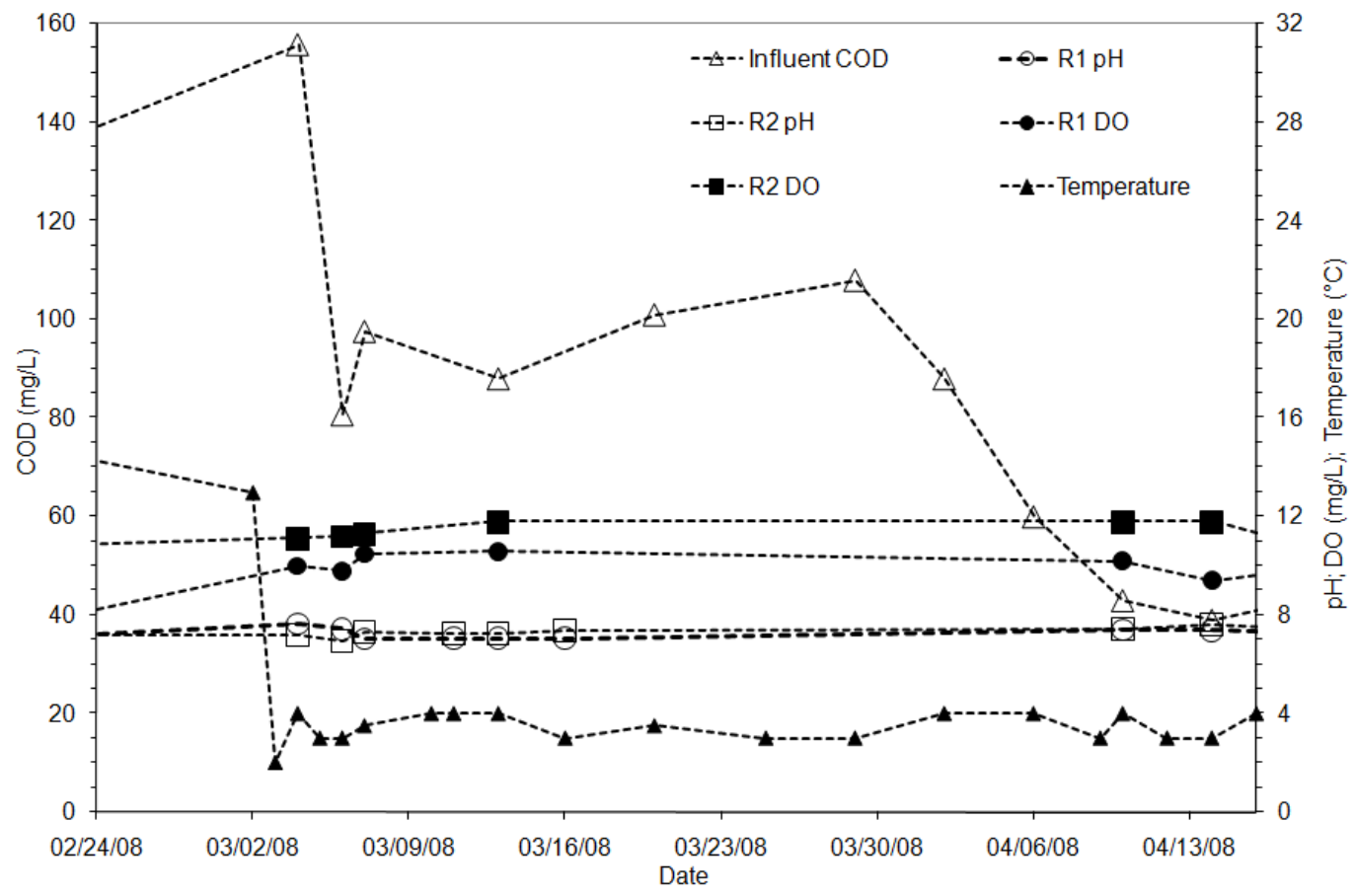

Fig. 3. Influent $\mathrm{COD}$ concentrations, $\mathrm{pH}, \mathrm{DO}$ and temperature conditions of the laboratory-scale reactors. 

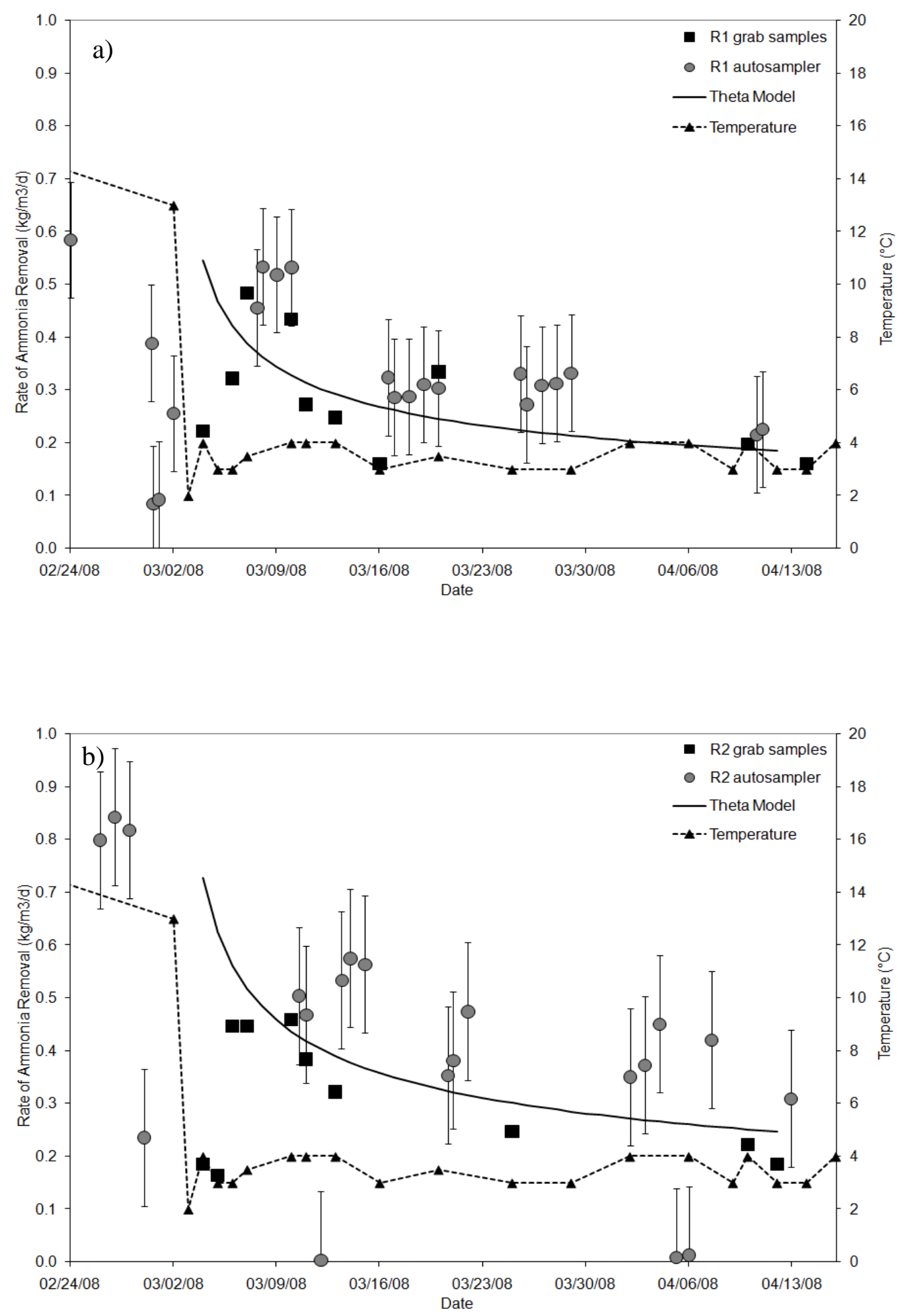

Fig. 4. Rate of ammonia removal in the laboratory-scale reactors; reactors R1 and R2 are shown in $4 \mathrm{a}$ and $4 \mathrm{~b}$, respectively. 


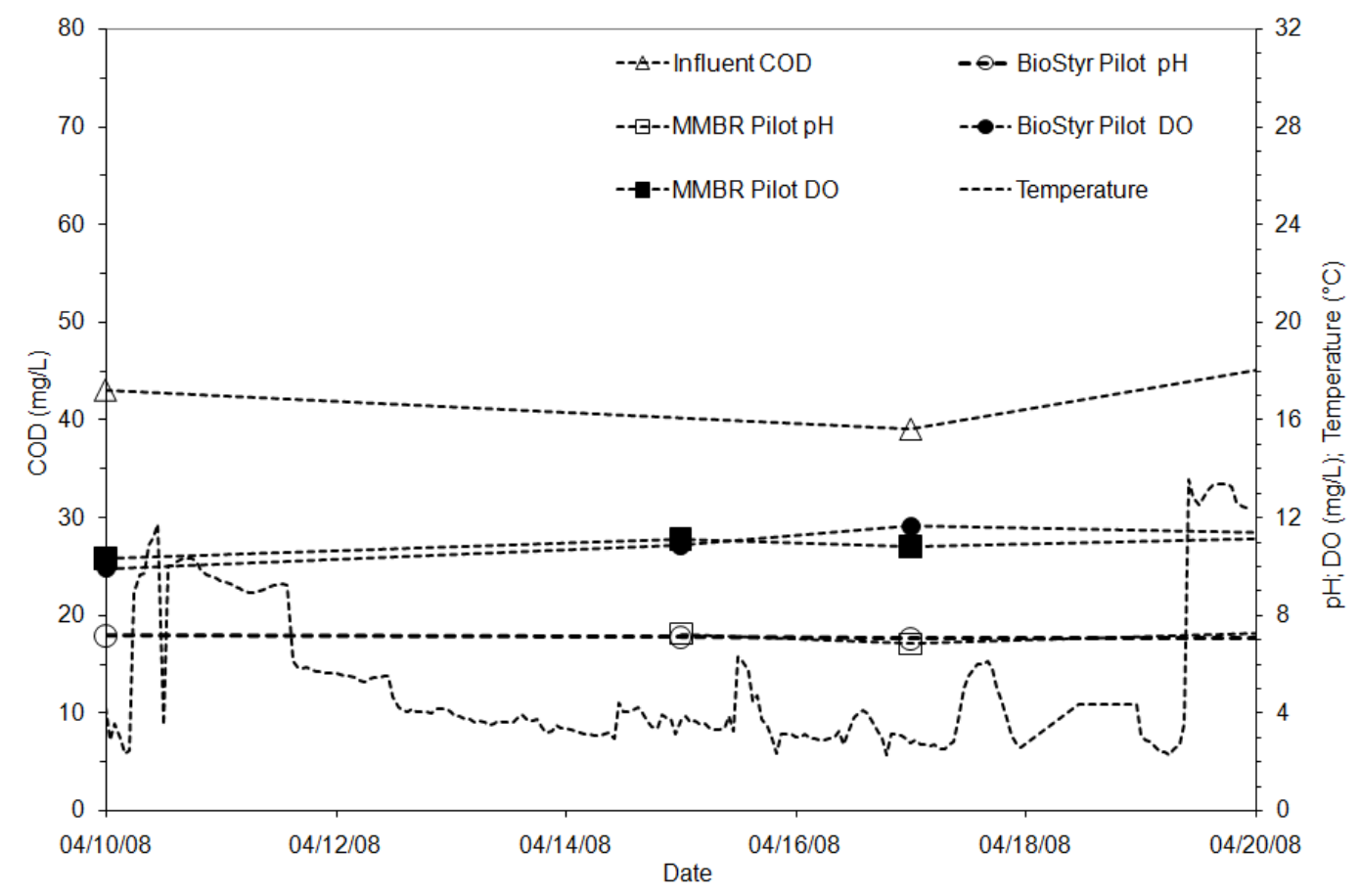

Fig. 5. Influent COD concentrations, $\mathrm{pH}, \mathrm{DO}$ and temperature conditions of the pilot-scale systems. 

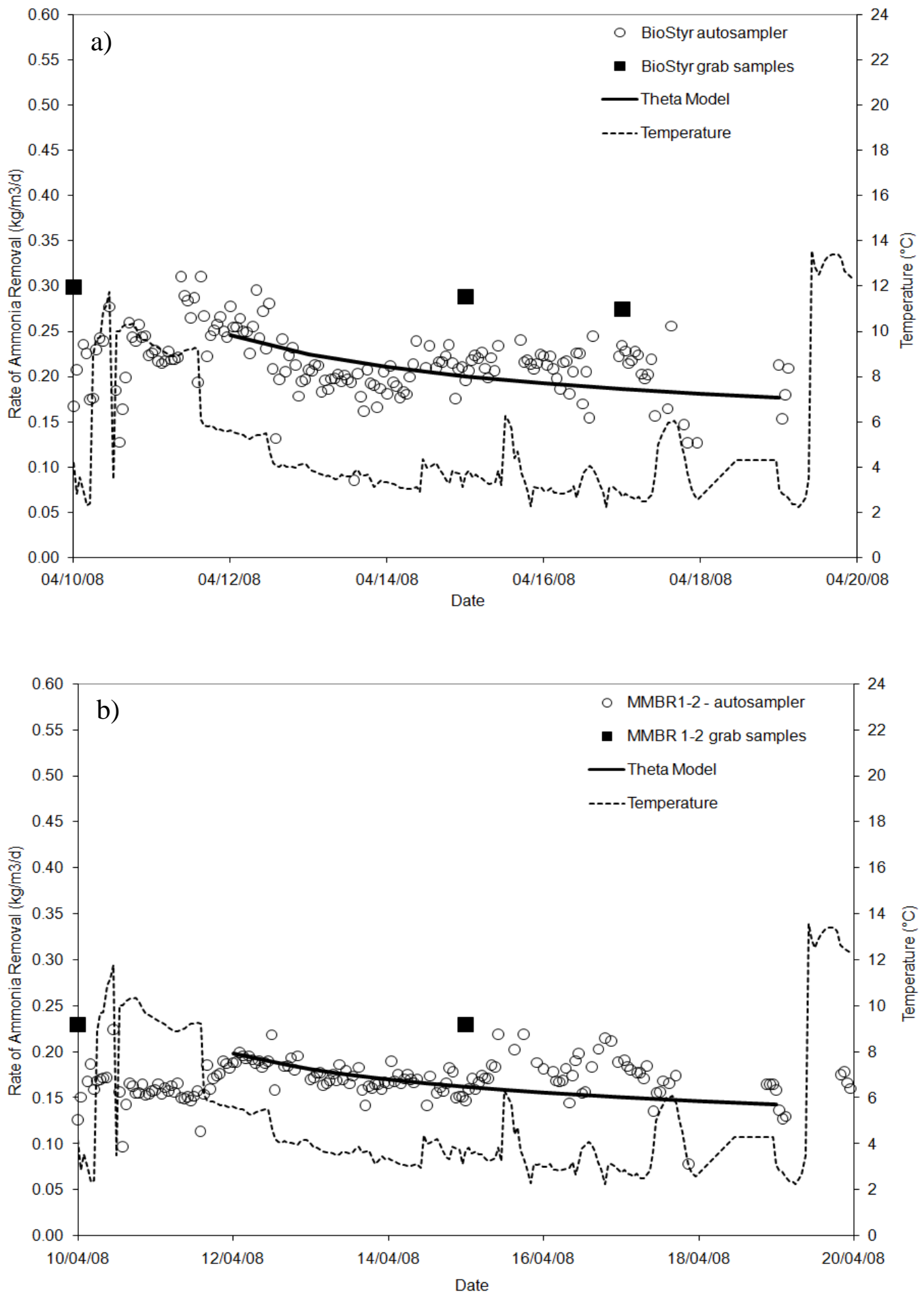

Fig. 6: Rate of ammonia removal in the pilot systems; BioStyr pilot and MMBR pilots are shown in $6 \mathrm{a}$ and $6 \mathrm{~b}$, respectively. 